\title{
Disclosing Accountability and Transparency of Village Fund Management
}

\author{
Yohanis Tasik Allo ${ }^{1}$, Carolus Askikarno Palalangan ${ }^{2}$ \\ Department of Accounting, Universitas Kristen Indonesia Paulus, Indonesia ${ }^{1,2}$
}

\{carolus@ukipaulus.ac.id $\left.{ }^{1}\right\}$

\begin{abstract}
This study aims to determine and describe the accountability and transparency of the management of village fund allocations in Gasing Village, Mengkendek District, Tana Toraja Regency. The approach method in this research is descriptive and qualitative. Sources of data used are primary data obtained by direct interviews and secondary data obtained from related documents. The results of the description are obtained through measurement by comparing the 2014 regulation on Permendagri 113 with actual field activities. The results of this study based on Permendagri 113 of 2014 show that the accountability in the management of village funds from reporting and accountability is quite good but there is still a slight deficiency in the allocation of village fund management in Gasing village, this is evidenced by the reporting that should be reported semiannually but in Gasing Village it is reported. on an annual basis, while in terms of transparency it is still not good enough where the community development planning meetings are only involved in the planning stage for the rest of the community is no longer involved.
\end{abstract}

Keywords: accountability; transparency; village funds

\section{Introduction}

Each year the costs that are devoted to villages are sent through the district / city regional income and expenditure budget for the development of rural areas, namely in the form of village treasury. The village was entrusted with the power to regulate the implementation of government in a self-sufficient manner in order to advance the peace and standard of living of the village community. In addition, local governments are also asked to be able to manage the government and its existing potential. (Law No.6 of 2014)

Such is the role of the village that is accepted by the village, of course it is accompanied by a large responsibility. Therefore, the village government must be able to apply the principle of accountability in its governance, where all must be accountable to the village community in accordance with the provisions. In carrying out the mandate, responsibilities and obligations to manage the village authority, it is requested that they be carried out openly and are accounted for properly. responsibility means providing or submitting financial reports to the wider community as well as village officials so that they can measure government accountability in all forms of activities carried out. 
Village funds are APBN allocated for villages that are transferred through district/city APBD and prioritized for the implementation of development and empowerment of village communities. An organization that deals with the public requires disclosure of information that can be accessed by the public as a form of public monitoring of the organization concerned. In an effort to create an information society that has the right to oversee the running of government, Law No. 14 of 2008 on public information disclosure was issued. Through this law, various issues of transparency of information, especially those related to or controlled by public agencies, must be made public as public information. Three important aspects of public transparency, namely:

a. The existence of an open policy towards supervision

b. The existence of access to information so that the public can reach every facet of government policies The

c. implementation of the principle check and balance (between executive and legislative institutions)

The level of accountability and transparency in the management of village funds is carried out with the principles of planning, implementation and accountability. Based on the information that has been obtained, Gasing Village, Mengkendek District, is one of the areas that has received quite a large amount of funds from the APBN, which is approximately 1 billion each year. These funds have been received since 2015. Therefore, by knowing these funds, some people in the village of Gasing think that there is a mismatch with the management of the existing funds. So researchers are interested in researching accountability and transparency in the management of village funds in Gasing Village, Mengkendek District, Tana Toraja Regency because they want to describe the accountability and transparency of the management of village fund allocation in the village.

\section{Method}

The type of research used in this study is qualitative. In this study, the researcher intends to discuss existing phenomena and describe matters related to the accountability and transparency of village fund allocation management in Gasing Village, Mengkendek District. Research informants are people who are used to provide information about the situation in the research field. The informants in this study are as follows:

Table 1. Name and Position who are used to provide information

\begin{tabular}{cll}
\hline No & \multicolumn{1}{c}{ Name } & \multicolumn{1}{c}{ Position } \\
\hline 1 & Adriana Ira Pasangka & Village Secretary \\
2 & Linus & Head of Dusun Baturondon \\
3 & Oktavianus & Head of RT Alla' \\
4 & Hermina & community \\
5 & Simon & community \\
\hline
\end{tabular}

The method of collection used in this study is using the observation method, interview methods, documentation methods, and literature study methods. Interviews were conducted with questions and answers between researchers and sources in order to obtain data directly from the object of research. As for the speakers in this study were Mrs. Adriana Ira Pasangka 'as the Village Secretary, Mr. Linus as the Head of Dusun Baturondon, Mr. Oktavianus as Head of RT Alla', and Mrs. Hermina and Mr. Simon as the community. The data analysis technique in this study is to use the Miles and Humberman model (in Sugiyono, 2016: 243) 
which includes 1) data collection, 2) data reduction, 3) data presentation, 4) drawing conclusions and giving suggestions.

\section{Results and Discussion}

\subsection{Accountability of Village Fund Allocation Management in Gasing Village.}

Accountability needs to be done through the media which can then be communicated to internal and external parties periodically or unexpectedly as a legal obligation and not voluntary. The use of the Village Fund Allocation received by the Village is used to finance the implementation of the Village government and community empowerment costs. Where the government running costs include the cost of maintaining the office and office environment of the village head, operational costs of the government implementation team, BPL allowances and operations, village head allowances, RT / RW honoraria, financial management honoraria, PKK honorarium and others. Meanwhile, the costs for community empowerment include the costs of building village facilities and infrastructure, PKK, youth organizations, spending on institutional strengthening and others.

Permendagri Number 113 of 2014 Article 37 states, the village head submits the realization of the implementation to the Regent / Mayor in the form of a first semester report in the form of a report on the realization of the APBDes submitted no later than July of the current year and a year-end semester report submitted no later than January of the following year. Meanwhile, the results of the interview from the village secretary (Mrs. Adriana Ira Pasangka) regarding reporting stated that the Village Head submitted a report on the realization of the APBDes through the sub-district head at the end of each year (December).

Table 2. Reporting Accountability Suitability Indicator According to Permendagri

\begin{tabular}{|c|c|c|}
\hline Indicators of & Interview Results & $\begin{array}{c}\text { 113/2014Descriptive } \\
(\mathrm{S}=\text { appropriate, } \mathrm{TS}= \\
\text { Not appropriate, } \mathrm{BT}= \\
\text { Not yet happened })\end{array}$ \\
\hline $\begin{array}{l}\text { The Village Head submits a report } \\
\text { on the realization of the APBDesa } \\
\text { implementation to the Regent / } \\
\text { Mayor in the form of a first } \\
\text { semester report and a year-end } \\
\text { semester report. }\end{array}$ & $\begin{array}{l}\text { The Village Head only submits } \\
\text { a report on the realization of the } \\
\text { APBDesa implementation to } \\
\text { the Regent / Mayor not every } \\
\text { semester but at the end of each } \\
\text { year }\end{array}$ & TS \\
\hline $\begin{array}{l}\text { First semester reports are in the } \\
\text { form of APBDesa }\end{array}$ & $\begin{array}{l}\text { realization reports. First } \\
\text { semester realization reports are } \\
\text { APBDesa }\end{array}$ & TS \\
\hline $\begin{array}{l}\text { First semester APBDesa } \\
\text { realization reports are submitted no } \\
\text { later than the end of July of the } \\
\text { current year. }\end{array}$ & $\begin{array}{l}\text { The report on the realization of } \\
\text { the first semester APBDes } \\
\text { implementation is reported by } \\
\text { the Village Head to the Regent } \\
\text { through the sub-district head at } \\
\text { the end of the year }\end{array}$ & TS \\
\hline
\end{tabular}




\begin{tabular}{llc}
\hline \multicolumn{1}{c}{ Indicators of } & Interview Results & $\begin{array}{c}\text { 113/2014Descriptive } \\
\text { (S= appropriate, TS }= \\
\text { Not appropriate, BT }= \\
\text { Not yet happened) }\end{array}$ \\
\hline $\begin{array}{l}\text { The end of year semester reports } \\
\text { are submitted no later than the end } \\
\text { of January of the following year. }\end{array}$ & $\begin{array}{l}\text { The end of year semester } \\
\text { reports are reported by the } \\
\text { Village Head to the Regent } \\
\text { through the sub-district head at } \\
\text { the end of the year (December) }\end{array}$ & TS \\
\hline
\end{tabular}

According to Permendagri Number 113 of 2014 concerning Village Financial Management, the Village Head stipulates a Gasing village regulation regarding APBDesa and has been agreed with the Lembang Consultative Body. The results of the interviews obtained regarding the Village Financial Management Accountability are:

"The accountability of Village Financial Management in Lembang Gasing is good, it is said to be good because the budget planned in each village work program has been realized and is right on target, for example in concrete rebates in Kabu, Tuan Sarong whose results now it is accessible for transportation and has been enjoyed by the community " (Mr. Linus, Sunday, July 05, 2020).

"In my opinion, the Village Financial Management Accountability in Lembang Gasing is still not good because the budgeted costs did not reach the work program being implemented, meaning that the planned village work program was implemented but the budgeted costs after implementation did not achieve the planned results, for example casting. the road in Kadingi Hamlet 'is still less than 10 meters and has not been cast than planned " (Mr Simon, Wednesday, 02 September 2020)

Table 3. Indicators of Accountability Accountability Suitability According to Permendagri 113/2014

\begin{tabular}{lll}
\hline \multicolumn{1}{c}{ Indicators of } & \multicolumn{1}{c}{ Interview Results } & $\begin{array}{l}\text { Information } \\
\text { (S= Appropriate, TS } \\
\text { = Not Suitable, BT }= \\
\text { Not yet Happened) }\end{array}$ \\
\hline $\begin{array}{l}\text { The Village Head submits an } \\
\text { accountability report for the } \\
\text { realization of the APBDesa } \\
\text { implementation to the Regent } \\
\text { / Mayor at the end of each } \\
\text { budget }\end{array}$ & $\begin{array}{l}\text { year.The Village Head submits an } \\
\text { accountability report for the } \\
\text { realization of the APBDesa } \\
\text { implementation to the Regent / } \\
\text { the realization of the }\end{array}$ & $\begin{array}{l}\text { Mayor at the end of the budget } \\
\text { year }\end{array}$ \\
$\begin{array}{l}\text { APBDesa implementation is } \\
\text { consists of revenue, } \\
\text { expenditure and financing } \\
\begin{array}{l}\text { Accountability reports for the } \\
\text { realization of APBDes } \\
\text { implementation are stipulated } \\
\text { by Village regulations }\end{array}\end{array}$ & $\begin{array}{l}\text { Accountability reports for the } \\
\text { realization of APBDesa } \\
\text { implementation consist of } \\
\text { income, expenditure and } \\
\text { financing. } \\
\text { Accountability reports for the } \\
\text { realization of APBDes } \\
\text { implementation are stipulated by } \\
\text { Village regulations }\end{array}$ & $\mathrm{S}$ \\
\hline
\end{tabular}

\subsection{Transparency Management of Village Fund Allocation}


Transparency is built on the basis of information flow which is free. All government processes, institutions and information need to be accessible to interested parties and the available information must be adequate so that it can be understood and monitored. (Ardianto.2007) The following are some information obtained regarding transparency obtained from interviews in Gasing Village. :

"In general, all village officials have conveyed the management of village fund allocations transparently to the community regarding the management of funds, for example the amount of funds that have been disbursed, the budget for village work programs is conveyed through musrembang and there are also information boards in the Lembang office" (Adriana Ira Pasangka'- Village Secretary, Thursday, July 16 2020).

"Regarding the management of the funds, we do have information that is usually conveyed directly in the Lembang deliberations and some can be seen on the announcement board at the Lembang office. In the deliberation of work programs, we are usually involved, but only in the planning for implementation, we are not included, like that(Mr. Oktavianus, Monday, July 20, 2020).

"For the management of village fund allocations, in my opinion, it cannot be fully transparent because if we are invited to the Lembang meeting we are informed that a number of funds that come from where they come from will be used or budgeted for this work program, but in the implementation of the program planned with the budget. those determined are not in accordance with what is in the field and after implementation it is not informed how much the fees will be used"'(Mrs. Hermina, Thursday 23 July 2020).

\section{Conclusion}

The accountability of village fund management at the reporting stage is said to be not yet accountable because it is not in accordance with the Regulation of Minister of Home Affairs 113 of 2014 where reporting should be submitted semiannually, but in Gasing village the reporting is annualized. The accountability of village fund management at the accountability stage is said to be accountable because it has used the accountability report format for the realization of the APBDes implementation according to Minister of Home Affairs Regulation $113 / 2014$ by including reports on village property, sectoral reports and regional programs that enter the village, as well as reports on the use of village funds for the fiscal year. It is said that transparency in the management of village funds in Gasing Village is not yet transparent because the implementation of the community work program is not involved.

\section{References}

[1] Anto, RP, \& Amir, M. (2017). Competence of Village Apparatus In Management of Village Funds in North Konawe Regency-Indonesia. IOSR Journal of Business and Management Ver. VII, 19 (11), 2319-7668.

[2] Awaliah, A., Nurmiati, \& Pariyati. (2019). Transparency and accountability of the management of village fund allocations in the village rose in the kecamatan dampal selatan, the district of Toli-toli. Journal of Collaborative Science, 1(1), 1334-1341.

[3] Bastian, I. (2015). Accounting for Districts and Villages. Jakarta, Erlangga Publisher. 
[4] Boučková, M. (2015). Management Accounting and Agency Theory. Procedia Economics and Finance, 25 (15), 5-13. https://doi.org/10.1016/S2212-5671(15)007078

[5] Directorate General of Fiscal Balance. 2017. Transfers to Regions and Village Funds. Http://www.djpk.depkeu.go.id. Retrieved September 20, 2017.

[6] Elif, Ş. (2015). Role Theory and Its Usefulness In Public Relations. European Journal of Business and Social Sciences, 4 (01), 136-143.

[7] Gayatri., Latrini, M Y. and NL Sari Widhiyani. 2017. Transparency and Accountability of Village Fund Financial Management to Encourage the Independence of Rural Communities. Journal of Applied Quantitative Economics, 10 (2), p. 175-182.

[8] Mariappan, SS and M. (2019). Implementation of Accountability and Transparency in the Management of Village Fund Allocation in Development (Case Study of Kuta Bakti Village, Babul Bakmur District, Southeast Aceh Regency) .3 (November). https://doi.org/10.1101/843326

[9] Minister of Home Affairs of the Republic of Indonesia. (2018). Minister of Home Affairs Regulation No. 20/2018 concerning Village Financial Management. Physical Review B, 72(10), 1-13. http://www.jdih.setjen.kemendagri.go.id/pm/Permendagri20 TH $2018+$

[10] No.Annex.pdf Nahruddin, Z. (2014). Accountability and Transparency of Village Allocation Fund Management in Pao-Pao Village, Tanete Rilau District, Barru Regency. Authority: Journal of Governmental Science, 4(2), 193-201. https://doi.org/10.26618/ojip.v4i2.95

[11] Putra, G., \& Karjati, PD (2019). Evaluation of Village Fund Management in Putren Village, Sukomoro District, Nganjuk Regency. Economie, 01(1), 62-74. https://journal.uwks.ac.id/index.php/economie/article/view/822

[12] Widyanti, R. (2018). Analysis of Accountability and Transparency of Village Fund Management in Nagari Ulakan, Ulakan Tapakis District. Lppm Umsb, XII(11), 118126.

[13] Wienda. (2018). Village Government Transparency and Accountability in Managing Village Fund Allocation. Journal of Accounting Science and Research, 5, 15. 